\title{
Peranan Mufti dalam Pentadbiran Ekonomi dan Sosial Negeri Johor, 1885-1941
}

\section{The Role of the Mufti in Johor's Economic and Social Administration, 1885-1941}

\author{
NOORILHAM ISMAIL \\ School of Humanities, Universiti Sains Malaysia, 11800 USM, Pulau Pinang, Malaysia \\ noorilham_ismail@yahoo.com
}

Published online: 31 May 2021

To cite this article: Noorilham Ismail. 2021. Peranan mufti dalam pentadbiran ekonomi dan sosial negeri Johor, 1885-1941. KEMANUSIAAN the Asian Journal of Humanities 28(1): 23-46. https://doi.org/10.21315/kajh2021.28.1.2

To link to this article: https://doi.org/10.21315/kajh2021.28.1.2

\begin{abstract}
This article analyses the role of the mufti of Johor in Malaya in confronting British imperialism between 1885 and 1941. It focuses on the mufti's role in the Johor government's economic and social matters in assuring the position of Islam in the state. Based on sources from Malaysian National Archive Johor's branch and secondary sources, the article discusses the administration of four muftis, Dato'Syed Salim Abdullah al-Attas, Dato' Abdullah Musa, Syed 'Abd Qadir Muhsin al-Attas and Syed Alwi Tahir al-Haddad. The focus is on the four muftis' role in the economic and social matters of the state related to muamalat laws as well as issues in education. The current study found that the muftis of Johor, 1885-1941, played a significant role in the economic and social matters of the state through informative and authoritative arguments.
\end{abstract}

Keyword and phrases: Johor's government, mufti, British imperialism, economy, social

\begin{abstract}
Abstrak. Artikel ini mengkaji peranan yang dimainkan oleh mufti kerajaan Johor dalam mendepani imperialisme British dari tahun 1885 hingga 1941. Tumpuan diberi kepada peranan mufti dalam urusan berkaitan ekonomi dan sosial kerajaan Johor bagi memastikan kedudukan agama Islam terus dipertahankan di negeri tersebut. Berdasarkan sumber-sumber yang diperoleh daripada Arkib Negara Malaysia Cawangan Johor dan sumber sekunder, makalah ini membincangkan pentadbiran empat orang mufti, terdiri daripada Dato' Syed Salim Abdullah al-Attas, Dato' Abdullah Musa, Syed 'Abd Qadir Muhsin al-Attas dan Syed Alwi Tahir al-Haddad. Menerusi peranan yang dimainkan oleh keempat-empat mufti berkenaan, kajian ini menilai aspek ekonomi dan sosial dalam kerajaan Johor yang mencakupi perkara-perkara yang berkaitan dengan hukum-
\end{abstract}

(C) Penerbit Universiti Sains Malaysia, 2021. This work is licensed under the terms of the Creative Commons Attribution (CC BY) (http://creativecommons.org/licenses/by/4.0/). 
hakam muamalat dan aspek pendidikan. Kajian ini mendapati bahawa mufti kerajaan Johor dalam era tersebut memainkan peranan dalam aspek ekonomi dan sosial menerusi hujahan yang informatif dan autoritatif.

Kata kunci dan frasa: kerajaan Johor, mufti, imperialisme British, ekonomi, sosial

\section{Pengenalan}

Institusi mufti merupakan satu bahagian penting dalam pentadbiran kerajaan Johor menjelang awal kurun ke-20. Institusi ini turut memainkan peranan penting dalam pentadbiran kerajaan Johor dari segi hal ehwal agama termasuk melibatkan ruang ekonomi dan sosial. Mereka terdiri daripada Dato' Syed Salim Abdullah al-Attas (1873-1899), Dato' Abdullah Musa (1899-1907), Syed 'Abd Qadir Muhsin al-Attas (1909-1933) dan Syed Alwi Tahir al-Haddad (1933-1941). Melalui fokus kajian ini, peranan mufti-mufti tersebut akan ditumpukan kepada usaha-usaha mendepani impak daripada imperialisme British dalam tempoh masa yang telah digariskan.

Sehingga kini, tidak banyak kajian berkaitan peranan mufti Johor dalam pentadbiran negeri direkodkan. Nurul Wahidah (2012) hanya memberi perhatian kepada Syed 'Abd Qadir Muhsin al-Attas dan Syed 'Alwi Tahir al-Haddad dalam konteks sumbangan Arab Hadhrami kepada pentadbiran kerajaan Johor sementara Abdul Latif (2012) pula hanya membincangkan secara umum berkenaan mufti kerajaan Johor sebelum Perang Dunia Kedua. Pengkaji lain seperti Ahmad Fawzi (1988), Emerson (1964) dan Sinclair (1967) turut membincangkan kedudukan kerajaan Johor dalam era imperialisme British tetapi tidak pula menyentuh peranan mufti dalam menghadapi tekanan Barat, sebaliknya fokus mereka hanya kepada sejarah pemodenan kerajaan Johor di samping aspek kepentingan ekonomi penjajah British. Selain itu, Abdul Rahman Tang (2007), Nadarajah (2000) dan Muhammad Izuan (2015) pula menyentuh tentang pemodenan Johor termasuk peranan Jabatan Agama Islam Johor tetapi tidak pula memfokus kepada peranan mufti terutama keempat-empat mufti yang dinyatakan sebelum ini. Perbincangan berikut dibuat berasaskan sumber daripada Arkib Negara Malaysia dan Arkib Negara Malaysia Cawangan Johor seperti dokumen J/MB (Pejabat Menteri Besar Johor), J/SUK 11 (Salinan Surat-Surat Datuk Menteri [SSDM]), J/UG X (Majalah Ahkam Johor) dan J/UG 7 (Jabatan Agama Islam Johor).

Bagi fail-fail $\mathrm{J} / \mathrm{MB}$, perihal pentadbiran kerajaan Johor diperincikan dalam bentuk surat-menyurat yang diterima dan dihantar oleh Menteri Besar Johor, Dato' Jaafar Haji Muhammad. Urus tadbir kerajaan Johor dari segi politik, 
ekonomi, dan sosial, khususnya sewaktu era pentadbiran Sultan Ibrahim pada penghujung kurun ke-19 dan awal kurun ke-20, telah menjadi intipati utama dokumen J/SUK 11. Fail J/UG X pula merupakan naskah Majalah Ahkam Johor yang telah diadaptasi oleh barisan mufti kerajaan Johor melalui rujukan kepada dokumen undang-undang dari kerajaan Uthmaniyyah yang pada asalnya bermazhab Hanafi. Di samping itu, J/UG 7 merupakan fail yang mengandungi gerak kerja mufti kerajaan Johor dari segi penghasilan fatwa, penyusunan sukatan pelajaran bagi sekolah agama termasuk catatan berkenaan hal ehwal solat, puasa, zakat, haji serta hal-hal berkaitan akidah.

Dari segi kepentingan kajian, penulisan ini dibuat bagi mengisi kekosongan yang terdapat dalam isu yang dibincangkan berkaitan mufti kerajaan Johor yang tidak disentuh oleh pengkaji sebelum ini. Aspek-aspek perbincangan turut dibuat bagi memperlihatkan bahawa barisan mufti dalam kerajaan Johor bukanlah satu kedudukan yang pasif ketika imperialisme British dari tahun 1885 sehingga 1941. Pada akhirnya, kajian ini sedikit sebanyak berusaha bagi menunjukkan bahawa aspek ekonomi dan sosial bukanlah suatu aspek yang terpisah daripada kaitannya dengan kedudukan mufti kerajaan Johor ketika itu.

\section{Tokoh-Tokoh Mufti dalam Kerajaan Johor (1885-1941)}

Sejarah institusi mufti di Johor telah bermula semenjak zaman kerajaan JohorRiau selepas berakhirnya dinasti kesultanan Melayu Johor yang merupakan waris kesultanan Melaka. Pada ketika itu, individu yang menyandang jawatan sebagai mufti sememangnya memainkan peranan penting dalam kerajaan JohorRiau daripada dinasti Bendahara (Abdul Latif dan Jainal 2008, 19). Walaupun begitu, perincian berkenaan peranan dan kedudukan mufti ini kabur kerana tiadanya penjelasan berkenaan institusi tersebut dalam catatan para sarjana. Namun demikian, institusi mufti ini telah mula diberi perhatian oleh Maharaja Abu Bakar semasa baginda memperkenalkan institusi ini secara rasmi dalam pentadbiran Johor moden pada tahun 1873 seiring dengan peletakan setiap mufti tersebut sebagai sebahagian daripada Ahli Jemaah Kerajaan Johor (Ahmad Fawzi 1997, 40). Perkara tersebut terbukti melalui kedudukan Syed Salim bin Abdullah al-Attas sebagai mufti pertama yang turut digelar "Sheikhul Islam" dan keadaan ini selaras dengan keutamaan agama Islam dalam pentadbiran kerajaan Johor ketika era pemerintahan Maharaja Abu Bakar. Dalam hal ini, pengertian mufti boleh difahami sebagai individu yang memiliki pengetahuan luas berkenaan Islam, bijaksana dan mampu membuat ketetapan berkenaan hukum Islam berdasarkan al-Quran dan sunnah. Keutamaan agama Islam ini terbukti melalui wasiat Temenggung Daeng Ibrahim kepada anakandanya, Maharaja Abu Bakar selepas kemangkatannya (S.7. 1857). Perkara ini kemudiannya berkesinambungan 
dengan ketika Maharaja Abu Bakar turut mewasiatkan perkara-perkara yang mempunyai kaitan dengan agama Islam kepada anakanda baginda, Sultan Ibrahim (S.7. n.d.).

Dalam sejarah, kedudukan mufti tidak pernah diwartakan pada kurun pertama selepas kewafatan baginda Nabi Muhammad SAW apatah lagi sewaktu hayat baginda. Hal ini demikian kerana selepas kewafatan baginda Rasulullah, kemaslahatan umat Islam berkenaan persoalan ad-Din (cara hidup yang diredai Allah) akan dirujuk terus kepada para sahabat khususnya sewaktu era Khulafa' ar-Rashiddin. Antara individu yang sering menjadi rujukan berkenaan persoalan berkaitan kemaslahatan Islam termasuklah Saidatina Aishah dan Saidina Ali dalam aspek hukum fikah, muamalat serta akidah. Namun begitu, jawatan mufti ini telah mulai diinstitusikan sewaktu pemerintahan Khalifah Umar Abdul Aziz daripada kerajaan Bani Umaiyyah (Ismail 1992, 40). Bermula dari situlah jawatan mufti ini telah wujud secara rasmi dan berkembang di wilayah-wilayah Islam yang baharu. Buktinya, institusi mufti telah ditubuhkan dalam kerajaan Islam di benua Afrika (Maghribi, Tunisia dan Libya) dan benua kecil India sewaktu era kesultanan Delhi di bawah pentadbiran Sultan Muhammad ibn Tughluq (Syed Nurul Akla dan Adi Setia 2003). Catatan tersebut terkandung dalam Rihlah Ibnu Batutah sekitar abad ke-14 Masihi yang kekal sehingga ke hari ini. Hal yang sama berlaku sewaktu zaman kerajaan Islam di Andalusia (Sepanyol) dan kerajaan Abbasiyyah di samping kerajaan Uthmaniyah yang turut mempunyai mufti dalam pentadbirannya. Oleh yang demikian, jawatan berkenaan terus berkembang sehingga menjangkau kerajaan Islam di Alam Melayu. Peranan mufti ternyata begitu besar sehingga mampu mempengaruhi pelantikan dan pemecatan khalifah atau sultan (Eeman 2002, 511).

Mufti pertama dalam kerajaan Johor moden ialah Dato' Syed Salim bin Abdullah al-Attas yang telah dilantik oleh Maharaja Abu Bakar pada tahun 1873. Tempoh perkhidmatan beliau selama 26 tahun iaitu dari tahun 1873 sehingga tahun 1899 (Abdul Latif 2012, 12). Beliau bukanlah anak jati Johor sebaliknya merupakan seorang yang berketurunan Arab Hadhrami yang datang dari Hadramaut, Yaman. Hal ini demikian kerana pada masa tersebut, berlaku proses penghijrahan dalam kalangan keluarga Arab Hadhrami ke kepulauan Melayu. Dato' Syed Salim al-Attas merupakan individu yang mempunyai ketinggian ilmu berkenaan Islam dan perkara ini kemudiannya telah menjadikan beliau sebagai individu penting dalam pentadbiran kerajaan Johor yang mengalami proses pemodenan. Beliau bukan sahaja menyandang jawatan sebagai mufti bahkan turut terlibat sebagai Ahli Jemaah Kerajaan Negeri Johor yang memiliki peranan besar dari segi pembuatan keputusan terutamanya dalam hal ehwal agama Islam. 
Selain itu, Dato' Abdullah Musa merupakan mufti kedua selepas mengambil alih jawatan tersebut dari Syed Salim al-Attas pada tahun 1899. Tempoh perkhidmatan beliau terlalu singkat iaitu hanya lapan tahun dari tahun 1899 sehingga 1907 (Ismail 1992, 40). Beliau dilahirkan di Kampung Pekan, Kelantan pada bulan April 1863. Beliau mendapat pendidikan awal di negeri kelahirannya sebelum berhijrah ke Johor pada 22 Disember 1882. Antara guru terawal beliau ialah seorang ulama terkenal iaitu Tok Kenali (Ahmad Fathy 2009, 24). Beliau sering kali berutus surat dengan gurunya berkenaan penyelesaian isu-isu berkaitan Islam dan keperibadian beliau turut terserlah dengan ketinggian ilmu pengetahuan khususnya dalam bidang agama dan pentadbiran.

Selepas Dato' Abdullah Musa meninggal dunia, warisan kepimpinan beliau sebagai mufti Johor diteruskan oleh Syed 'Abd Qadir Muhsin al-Attas. Beliau telah mengambil jawatan sebagai pemangku pada tahun 1907 sebelum dilantik secara rasminya pada tahun 1909. Syed 'Abd Qadir dilahirkan pada 20 Julai 1867 di Seri Langkat Sumatera, Indonesia. Beliau merupakan keturunan keluarga Arab Hadhrami seperti Syed Salim Abdullah al-Attas. Pendidikan awal beliau adalah di Sekolah Melayu Johor Bahru sebelum melanjutkan ke peringkat yang lebih tinggi di Mekah. Dengan asas agama Islam dan pengetahuannya yang luas, Syed 'Abd Qadir al-Attas telah dilantik sebagai naib mufti pada 1 Oktober 1901. Dari tahun tersebut sehingga 1909, beliau turut dilantik oleh Sultan Ibrahim sebagai pembantu Hakim Besar Johor untuk mentadbir perkara-perkara berkaitan 20 perundangan Islam di Johor (J/DUN 7 1934). Keadaan tersebut selaras dengan keutamaan agama Islam yang telah ditetapkan dalam pentadbiran kerajaan Johor. Beliaujuga telah berkhidmat sebagai mufti selama 24 tahun dari tahun 1909 sehingga 1933 (Abdul Jalil 2002, 102). Kehadiran beliau sebagai mufti kerajaan Johor amat penting kerana sepanjang tempoh masa tersebut, penguasaan pihak British dalam kerajaan Johor telah diperkukuh dengan pelantikan seorang Penasihat Am, Sir Douglas Campbell (Ahmad Fawzi 1988, 63). Sungguhpun demikian, peranan Syed 'Abd Qadir al-Attas sebagai mufti Johor begitu penting pada ketika itu. Pada tahun 1933, beliau telah melepaskan jawatan mufti yang disandangnya selama 24 tahun.

Syed Alwi Tahir al-Haddad merupakan mufti keempat dalam susur galur jawatan tersebut dalam pentadbiran Johor. Beliau telah menggalas tanggungjawab berkenaan daripada Syed Abdul Qadir al-Attas yang telah bersara pada tahun 1933. Pada asalnya, beliau merupakan tokoh ulama yang terkenal dari Hadramaut dan Nusantara (Abu Bakar dan Md Ismail 2003, 34). Jurai keturunannya dikatakan berkait dengan keturunan Saidina Ali bin Abu Talib melalui perkahwinannya dengan Siti Fatimah iaitu puteri Rasulullah SAW (Nurul Wahidah 2012, 90). 
Syed Alwi al-Haddad lahir di bandar Qaidun, Hadramaut pada 7 Ogos 1884. Beliau merupakan individu yang berpengetahuan luas dalam bidang syariah dan usuluddin serta mendapat pendidikan daripada ulama muktabar. Beliau juga aktif dalam penulisan berbentuk kitab-kitab yang mencerminkan ketinggian ilmu pengetahuan. Antara karya beliau ialah Anwar Al-Quran Almahiyyah Li Talamat Mutanabi' Qadiyyani, Alqaul Alfashl Fi Ma Li Alarab Wa Bani Hashim Alfadhl, Alkhulasah Alwafiyah Fi Alasanid Aliyah, 'Iqd Alyayakut Fi Tarikh Hadramaut dan kitab Sirah Annabiayah Alsyarifah. Penulisan-penulisan tersebut berkait dengan ilmu sirah Rasulullah, persoalan berkaitan qiraat dan panduan akidah Islam. Dalam hal ini, kesemua mufti yang dinyatakan sebelum ini memainkan peranan penting dalam pentadbiran kerajaan Johor khususnya dalam tempoh imperialisme British pada masa tersebut.

\section{Imperialisme British dalam Kerajaan Johor (1885-1941)}

Pada penghujung kurun ke-19, Johor tertakluk di bawah pengaruh imperialisme British sebaik sahaja Perjanjian Persahabatan 1885 termeterai. Keadaan tersebut berlaku disebabkan banyak perkara yang berkaitan dengan pentadbiran kerajaan Johor terutama dari segi hubungan luar telah berada dalam kawalan British. Hal ini disebutkan dengan jelas dalam fasa perjanjian berkenaan yang dinyatakan sebagai:

The two Governments with at all times cordially co-operate in the settlement of a peaceful population in their respective neighbouring territories, and in the joint defence of those territories from external hostile attacks and in the mutual surrender of persons accused or convicted of any crime or offence, under such conditions as may be arranged between the two Governments. (Perjanjian Pesahabatan 1885)

Dalam hal ini, kerajaan Johor juga terhalang daripada menandatangani apa-apa perjanjian atau membuat sebarang perikatan dengan mana-mana kuasa lain yang melibatkan soal hubungan luar tanpa persetujuan pihak British. Pada dasarnya, perkara ini merupakan satu lanjutan pengaruh British terhadap kerajaan Johor selepas negara Anglo-Saxon tersebut memainkan peranan penting di sebalik pertabalan Maharaja Abu Bakar sebagai Sultan Johor sebelum perjanjian persahabatan tersebut (CO 273/416 1877).

Dari sudut imperialisme British, empayar berkenaan sememangnya sedang giat memperluaskan pengaruhnya di rantau Asia Tenggara pada kurun ke-19. Perkara ini diperkukuhkan lagi setelah termeterainya Perjanjian Inggeris-Belanda pada tahun 1824 yang telah membentuk lingkungan kawasan di bawah pengaruh 
dua kuasa imperialis berkenaan di Asia Tenggara. Perjanjian ini menetapkan sempadan kuasa British dan Belanda di Alam Melayu dengan meletakkan satu garis melintang pada peta di bawah Singapura. Perjanjian ini menyebut bahawa British tidak mempunyai hak dalam sebarang hal di Pulau Karimun, Batam, Riau, Lingga dan pulau-pulau di selatan Singapura sementara Belanda pula hilang hak terhadap Singapura dan wilayah di utaranya. Melaka diserahkan semula kepada British dan Bencoolen diserahkan kepada Belanda (Emerson 1964, 51). Dalam tempoh ini, pengaruh British kemudiannya dikukuhkan lagi melalui penubuhan Negeri-Negeri Selat (NNS) yang digabungkan sebagai Tanah Jajahan Mahkota British terdiri daripada Singapura, Melaka dan Pulau Pinang. Strategi ini telah menjadikan kedudukan British lebih kukuh di Asia Tenggara pada kurun ke-19 sebagai sebuah kuasa besar yang berpengaruh di rantau berkenaan tetapi masih tidak melaksanakan polisi campur tangan secara terus terhadap negeri-negeri Melayu di sekitarnya (Turnbull 1972, 271). Pada dasarnya, tempoh pertengahan kurun ke-19 ini masih belum memperlihatkan sebarang campur tangan secara terus oleh pihak British terhadap negeri-negeri di Tanah Melayu kerana lingkungan kawasan ini dilihat sebagai laluan untuk kuasa imperialis tersebut ke China serta India (Cowan 1961, 5).

Keadaan berkenaan kemudiannya berubah sebaik sahaja Perjanjian Pangkor ditandatangani oleh wakil British, Sir Andrew Clark dengan Sultan Abdullah dari Perak pada 20 Januari 1874. Perjanjian ini telah menyaksikan bermulanya fasa baharu yang menjadikan British sebagai kuasa tunggal di Tanah Melayu sehingga setelah tercetusnya Perang Pasifik. Perjanjian ini juga telah memperlihatkan pihak British sebagai kuasa yang menentukan hal ehwal pentadbiran dan ekonomi di bawah arahan seorang residen. Berkenaan urusan berkaitan hal ehwal agama Islam dan adat istiadat Melayu, perkara tersebut turut diganggu oleh pihak British dari segi tadbir urusnya khususnya sewaktu Negeri-Negeri Melayu Bersekutu (NNMB) ditubuhkan pada tahun 1896. Melalui penubuhan NNMB ini, pentadbiran British di negeri-negeri Melayu yang terlibat telah dipusatkan melalui peranan pentadbiran yang lebih kukuh dari segi kuasa dan autoriti kepada pentadbir British (Yegar 1979, 187). Keadaan ini telah menyebabkan urusan-urusan pentadbiran dari segi politik, ekonomi dan sosial dalam NNMB menjadi lebih selaras di samping pembuatan keputusan yang lebih terpusat kepada Residen Jeneral ketika itu. Hal ini telah membuktikan bahawa imperialisme British bukan sahaja menjejaskan soal politik dan ekonomi dalam kalangan negeri-negeri Melayu namun turut mengganggu kedudukan agama Islam itu sendiri lalu perkara tersebut telah mewujudkan reaksi dalam kalangan pemimpin Johor khususnya pihak mufti dari segi kesediaan menghadapi ancaman British terutama dalam aspek ekonomi dan sosial. 
Perlu ditegaskan bahawa tempoh penghujung kurun ke-19 ini dilihat sebagai era imperialisme baharu dalam kalangan kuasa-kuasa Barat menerusi usahausaha untuk mendapatkan wilayah tanah jajahan masing-masing atas dorongan penguasaan ekonomi khususnya bermula pada tahun 1870 seperti yang dinyatakan oleh sarjana British, J.A. Hobson (1902). Keadaan ini diperlihatkan dengan jelas setelah banyak kawasan tanah jajahan yang kaya dengan sumber asli seperti timah, balak, getah, koko dan bijih besi jatuh dalam kekuasaan imperialis Barat seperti Jerman, Perancis serta Amerika Syarikat. Dalam hal ini, British tidak terkecuali dengan kuasa imperialis berkenaan semakin memperluas wilayah jajahannya meliputi kawasan di bahagian Amerika Utara (Lafeber 1967) dan penjajahan benua Afrika yang memberi pulangan ekonomi kepada British (Gallagher dan Robinson 1981). Hobson menjelaskan era imperialisme baharu ini sebagai:

Imperialism, as we see, implies the use of the machinery of government by private interests, mainly capitalists, to secure for them economic gains outside their country. The dominance of this factor in public policy imposes a special character alike upon expenditure and taxation. (Hobson 1902, 94)

Peluasan kawasan jajahan ini merupakan satu tambahan buat empayar British selepas kuasa besar berkenaan berjaya menakluki India, China dan Burma di Asia Tenggara. Bagi Tanah Melayu, era imperialisme baharu ini telah menyaksikan campur tangan secara langsung oleh pihak British terhadap negeri-negeri Melayu bermula dengan Perak, diikuti oleh Selangor, Negeri Sembilan dan Pahang (Khoo 1972; Sadka 1968; Parkinson 1960; Wong 1990).

Menjelang tahun 1916 pula, Vladimir Il'ch Lenin yang telah menggerakkan revolusi Rusia turut mengukuhkan lagi tesis Hobson sebelum ini. Hal ini kerana Lenin melihat kuasa-kuasa besar Eropah yang giat meluaskan tanah jajahan masing-masing pada penghujung kurun ke-19 dan awal kurun ke-20 tidak lain hanyalah berdasarkan dorongan ekonomi. Lenin (1939) turut menyifatkan tindakan kuasa-kuasa besar tersebut semata-mata didorong oleh dasar luar yang kapitalistik sehingga membawa kepada berlakunya imperialisme.

Imperialisme British kemudiannya tidak terbatas kepada kepentingan ekonomi itu sahaja, bahkan turut diikuti dengan penyebaran ajaran Kristian dalam kurun ke-19. Perkara tersebut terjadi lantaran golongan mubaligh Kristian yang sebahagian besarnya terdiri daripada rahib-rahib wanita telah turut serta dalam pengembangan tanah jajahan dengan usaha untuk menyebarkan ajaran Kristian (Thompson 2005, 310). Mereka akan terlibat dengan saluran pendidikan melalui sekolah-sekolah yang dibina di kawasan NNS. Meskipun penyebaran ajaran 
Kristian ini bukanlah satu polisi rasmi kerajaan British terhadap tanah jajahannya, namun hal tersebut menjadi ancaman terutamanya terhadap negeri-negeri Melayu yang menjadikan Islam sebagai pegangan dan cara hidup (Nabir 1990, 117).

Ekoran daripada peluasan imperialisme British yang dinyatakan sebelum ini, pemerintah kerajaan Johor telah mengorak langkah untuk membangunkan Johor ke arah kemajuan melalui pemodenan dalam aspek pentadbiran. Temenggong Ibrahim (1825-1862) dan anaknya, Abu Bakar (1862-1895) mengambil langkah yang bijak dengan membawa masuk teknik dan idea Barat dalam pentadbiran kerajaan. Proses ini dilihat sebagai pembaratan kerajaan Johor dengan membawa nilai-nilai pemodenan yang berguna untuk sebuah kerajaan. Mulai tahun 1886, Johor mempunyai Lembaga Penasihat yang berpusat di London bagi mengurus dan menasihat hal pentadbiran Johor di dalam dan di luar negeri. Pada tahun 1873, Johor telah mempunyai jabatan-jabatan dalam struktur pemerintahannya seperti Jabatan Bendahari, Jabatan Mahkamah, Jabatan Polis, Jabatan Penjara, Jabatan Ukur, Jabatan Laut, Jabatan Perubatan dan Jabatan Keretapi (Siti Zahrah 2018, 48).

Pada suku keempat kurun ke-19 itu juga, pemodenan kerajaan Johor tidak terletak semata-mata pada penyusunan sistem pentadbiran dan pembangunan dari segi fizikal, bahkan usaha ke arah membentuk satu falsafah pentadbiran moden turut dijelmakan oleh pemerintah. Hal ini terbukti melalui pelaksanaan UndangUndang Tubuh Kerajaan Johor yang dimahsyurkan pada bulan April 1895 oleh Maharaja Abu Bakar. Pemodenan yang dilakukan ini tidak mengabaikan sama sekali kedudukan agama Islam bahkan turut meletakkan Islam sebagai keutamaan (Abdul Rahman Tang 2007, 211).

Perkara berkaitan agama Islam dalam Undang-Undang Tubuh Kerajaan Johor terlihat dalam Fasal 40 dan 57 (J/PU 3 1895). Perkara tersebut memperlihatkan pentingnya agama Islam sebagai elemen yang signifikan dalam struktur pentadbiran kerajaan Johor. Kedudukan agama Islam itu dinyatakan dalam Fasal 57 seperti berikut:

Adalah yang dikatakan "agama negeri” dan jajahan Kerajaan Johor ini iaitu agama Islam maka yang demikian hendaklah agama Islam itu berpanjangan dan berkekalan selama-lamanya menjadi dan diaku dan disebut sebagai "agama negeri" yakni tiadalah sekali-sekali boleh sebarang agama lain. Dijadikan atau disebut agama negeri sungguhpun segala agama lain ada dibenarkan dan sentiasa termaklum patut dibenarkan dengan aman dan sempurna boleh diperagamakan dalam segala segenap daerah takluk kerajaan Johor yang beragamakan ia. 
Penjelasan tersebut diperkuatkan lagi pada fasal sebelumnya iaitu Fasal 40 (J/PU 3 1895) yang menyatakan bahawa:

Berbuat satu kesalahan yang berat dosanya pada hukum syariat atau pada undang-undang negeri atau pada pertimbangan istiadat kehormat dan yang telah didapati dengan cukup siasat telah terang didapati ia berdosa iaitu menderhaka atau cuba hendak menderhaka kepada Raja atau kerajaan atau membunuh orang atau merompak dan menyamun atau cuba berbuat sesuatu daripada itu atau makan suap atau cuba hendak menyuap atau suatu lain perbuatan yang jahat dan berdosa pada hukum Allah dan hukum negeri.

Dalam hal ini, kedudukan Islam dalam pentadbiran kerajaan Johor telah mempengaruhi tindakan serta keputusan ahli Jemaah kerajaan Johor. Perkara ini kemudiannya dicerminkan melalui pentadbiran dalam aspek ekonomi dan sosial kerajaan Johor bagi tempoh penghujung kurun ke-19 di samping awal kurun ke-20. Justeru, barisan mufti kerajaan Johor seperti yang dinyatakan sebelum ini telah memainkan peranan masing-masing dalam memastikan kedudukan Islam dalam kerajaan Johor terus dipertahankan ketika era imperialisme British. Lebih menarik lagi, aspek ekonomi dan sosial berasaskan Islam turut tidak terkecuali daripada menerima perhatian barisan mufti tersebut.

\section{Peranan Mufti dalam Aspek Ekonomi Kerajaan Johor (1885-1941)}

Pada 11 Mei 1914, satu perjanjian baharu telah dipersetujui antara Sultan Ibrahim bagi pihak kerajaan Johor dengan Gabenor Sir Arthur Henderson Young, wakil kerajaan British. Lanjutan perjanjian ini, seorang Penasihat Am telah dilantik. Bermula daripada tarikh tersebut, segala nasihat Penasihat Am mestilah dipatuhi. Penasihat Am tidak boleh lagi disifatkan sebagai pegawai yang dipinjamkan oleh kerajaan kolonial, tetapi mereka hendaklah diterima sebagai wakil kerajaan kolonial seperti wakil-wakil British yang lain di Tanah Melayu (Ichiro 2011, 15). Dalam perubahan tersebut, pentadbiran kolonial terus-menerus mengkritik struktur pentadbiran sultan dalam pelbagai aspek khususnya undangundang dan pengurusan kewangan (CO 273/406 1914). Dari segi ekonomi yang bercanggah dengan Islam pula, keadaan demikian telah berlaku sebelum campur tangan British secara langsung ke atas pentadbiran Johor. Hal ini terbukti dengan wujudnya kegiatan ekonomi seperti perniagaan candu dan kegiatan perjudian. Keadaan tersebut dapat dilihat melalui fail Menteri Besar Johor ketika itu yang menyebutkan antara lainnya, usaha-usaha untuk merombak kegiatan pajak judi yang berkaitan dengan umat Islam pada tahun 1896 (J/SUK 11 1896a; J/SUK 11 1896b). Keadaan ini menunjukkan bahawa telah wujud unsur kegiatan ekonomi Barat yang secara jelas bercanggah dengan syiar dan syariat Islam. 
Kegiatan perjudian itu sendiri misalnya bercanggah dengan syiar dan syariat Islam kerana mengandungi unsur penindasan dan kesamaran di samping secara jelas telah diharamkan dalam kitab al-Quran yang menjadi panduan umat Islam keseluruhannya.

Pada masa yang sama, kegiatan berkaitan perniagaan candu turut tumbuh dengan pesat. Hal ini demikian kerana perniagaaan tersebut membawa keuntungan yang lumayan kepada pihak yang terlibat. Pada masa tersebut, perdagangan candu bergerak melalui pemodal Cina yang terdiri dari kelompok Gee Hin yang dibawa oleh pemerintah Johor sejak dari tempoh pemerintahan Temenggung Daeng Ibrahim lagi (Ahmad Fawzi 1988, 43). Meskipun pada ketika itu British masih belum menguasai Johor, namun corak ekonomi yang berorientasikan ekonomi Barat muncul dan bergerak pesat khususnya di kawasan-kawasan bandar seperti Johor Bahru, Batu Pahat dan Muar. Permasalahan berkaitan perniagaan candu boleh dilihat berdasarkan kes "Kongkek dan Kongsoh" berkaitan candu pada tahun 1896 melalui surat yang dihantar kepada Setiausaha Kerajaan Johor, Abdul Rahman Andak. ${ }^{9}$ Kandungan surat tersebut secara ringkasnya memperlihatkan pertelingkahan yang timbul kesan daripada perniagaan candu yang wujud ketika itu. Justeru, unsur ekonomi yang bertentangan dengan Islam ternyata telah bertapak dalam ruang ekonomi Johor.

Selain itu, orientasi pemilikan tanah di Johor turut berubah mengikut pelaksanaan Undang-Undang Tanah British. Perkara tersebut terbukti dalam Pindaan Enakmen Tanah 1910 dan Perundangan Tanah Johor 1910 (J/PP 114 1910). Situasi tersebut membuktikan betapa British ghairah untuk menguasai salah satu daripada faktor peluasan dalam kegiatan ekonomi iaitu tanah. Seiring dengan itu, muncullah kegiatan perekonomian baharu seperti penanaman getah dan kopi di Johor yang digerakkan oleh pelabur-pelabur Eropah.

Di samping itu, hak pemilikan tanah oleh orang Melayu turut terjejas. Tanah-tanah yang ada telah menjadi milik British dan saudagar yang terdiri daripada orang Cina dan individu berketurunan Arab. Bagi mengelakkan perkara tersebut terus berleluasa, satu undang-undang berkenaan pemilikan tanah orang-orang Melayu telah digubal iaitu Undang-Undang Tanah yang Dicadangkan kerana OrangOrang Melayu 1936. Inisiatif ini bertujuan untuk menjamin hak orang Melayu terhadap pemilikan tanah-tanah mereka. Dalam konteks undang-undang ini, tanah milik Melayu ditakrifkan sebagai:

Sebarang faedah seorang Melayu yang telah didaftarkan menjadi tuan punya atau tuan punya bersekutu bagi sebarang tanah yang telah dikurniakan yang termasuk dalam tanah yang dicadangkan kerana 
orang-orang Melayu yang telah sempurna dimasyhurkan dan dizahirkan dalam Warta Kerajaan. (J/PU 1 1936)

Dalam hal ini, imperialisme British ternyata telah menggugat hak material rakyat dalam kerajaan Johor dari segi ekonomi yang kemudiannya turut mencakupi aspek ekonomi berkaitan Islam. Pihak pentadbir British bukan sahaja telah mengeksploitasi aspek pemilikan tanah bahkan turut mengganggu pentadbiran ekonomi yang berteraskan Islam seperti kegiatan zakat, wakaf, pengurusan baitulmal dan urusan bagi ibadah haji (Yegar 1979, 205-232). Kesemua bentuk muamalat dan ibadah orang Islam seperti yang telah dinyatakan tertakluk di bawah urusan pentadbir British sama ada dari segi kawalan, penapisan dan pengurusan setiap jabatan agama yang terlibat.

Bagi menjaga kemurnian agama Islam sebagai agama yang menjadi teras dalam kerajaan Johor, Sultan Ibrahim melalui kuasa yang dimilikinya telah memerintah dan meletakkan amanah yang besar kepada Syed 'Abd Qadir yang bukan hanya bertindak sebagai mufti, bahkan sebagai penasihat undang-undang agama Islam kerajaan Johor. Usaha ini dapat dilihat sewaktu baginda mengambil Majalah Ahkam al-Adliyyah untuk diterjemahkan ke dalam bahasa Melayu sebagai Majalah Ahkam Johor serta dijadikan panduan rasmi berkenaan hukum syarak dalam kerajaan Johor pada tahun 1913 (Abdul Jalil 2002). Hal ini sekali gus menjadi suatu kodifikasi undang-undang yang seragam untuk seluruh Johor pada waktu itu. Pada asalnya, kod undang-undang ini telah dibawa masuk ke Johor dari kerajaan Uthmaniyyah (Turki pada hari ini) sewaktu lawatan Maharaja Abu Bakar ke negara tersebut pada 1878. Secara terasnya, kandungan asal Majalah Ahkam al-Adliyyah ini berlandaskan mazhab Hanafi yang kemudiannya telah dirangka semula berlandaskan mazhab Syafi'i. Hal ini merupakan langkah baginda dalam usaha meletakkan dan menyerapkan undang-undang Islam dalam sistem perundangan dan kehakiman kerajaan Johor. Syed 'Abd Qadir yang ditugaskan sebagai mufti dan Ketua Hakim Mahkamah pada tahun 1912 telah memainkan peranan yang besar dalam usaha menjadikan Majalah Ahkam Johor sebagai mempengaruhi pentadbiran mahkamah serta pentadbiran agama secara seragam. Penggunaan majalah ini yang dikenal pasti telah berkuatkuasa semenjak tahun 1893 membuktikan perkara tersebut. Namun demikian, kewujudan undangundang Majalah Ahkam al-Adliyyah dalam pemakaian fatwa kelihatan secara jelas sewaktu pemerintahan mufti terawal, iaitu pada zaman Syed Salim bin Abdullah al-Attas dan Dato' Abdullah Musa. Walaupun begitu, naskhah asal Majalah Ahkam al-Adliyyah ini ditulis dalam bahasa Arab dan penggunaannya terhad kepada pentadbir kerajaan Johor sahaja. Oleh hal yang demikian, kajian ini melihat bahawa sumbangan yang dilakukan oleh Syed 'Abd Qadir jelas terbukti 
melalui usaha-usaha penterjemahan Majalah Ahkam al-Adliyyah tersebut yang dilakukan di Matba' Khairiyyah, Muar bertarikh 1331 AH. Perkara ini dinyatakan dalam surat daripada Dato' Pemangku Setiausaha Kerajaan Johor bilangan 998/13 bertarikh 29 November 1913 bahawa:

Adalah kitab ini mengandungi di dalamnya bicara-bicara hukum fiqh yang diterbitkan daripada syariat Islam dan yang telah dipakai dalam kerajaan Johor selamanya dengan bahasa Arab yang demikian diterjemahkan ke dalam bahasa Melayu supaya menjadikan lebih senang mengerti dan mengambil fahamnya. (J/UG X n.d.)

Kenyataan daripada surat tersebut telah memperakui bahawa mufti kerajaan Johor berkenaan telah menjalankan tugas menterjemah salinan berkenaan ke dalam bahasa Melayu supaya lebih difahami. Perkara ini penting bagi proses penyampaian hukum-hakam khususnya yang berkaitan dengan soal muamalat khususnya tentang perkara-perkara berkaitan jual beli dan urusan ekonomi. Selanjutnya, surat berkenaan turut menyatakan:

\begin{abstract}
Bahawasanya dengan persetujuan dan ittifak pegawai-pegawai terutama bagi jabatan agama dan yang berkenaannya dan setelah disahkan terjemahannya maka dipersembahkan kepada maklum ke bawah Duli Yang Maha Mulia Ibrahim Sultan Yang Dipertuan Johor dipohonkan kebenaran supaya dicop (dicetak) oleh kerajaan ditetapkan dipakai menjadi sebuah daripada kitab-kitab panduan berkenaan dengan hukumhukum syarii (menurut bagaimana kecualian yang disebutkan dalam undang-undang tubuh kerajaan Johor fasal yang ke-49) serta dinamakan ia "Majalah Ahkam Johor". (J/UG X n.d.)
\end{abstract}

Usaha-usaha penterjemahan Majalah Ahkam Johor ini kemudiannya diperakui oleh Sultan Ibrahim sebagai dokumen yang perlu untuk perjalanan pentadbiran berkaitan Islam dalam kerajaan Johor. Kandungan dalam majalah berkenaan perlulah difahami dan menjadi panduan dalam kalangan pegawai dalam kerajaan Johor sama ada di peringkat pusat mahupun daerah. Selain itu, gerak kerja Syed 'Abd Qadir berkaitan Majalah Ahkam Johor ini dapat dilihat ketika beliau meletakkan Majalah Ahkam Johor sebagai satu dokumen yang penting bagi pentadbiran kerajaan Johor selaras dengan akta yang dikuatkuasakan oleh Sultan Ibrahim dalam Fasal 49 dan 57 (J/UG X n.d.). Perkara tersebut dinyatakan sebagai:

Bahawa adalah ke bawah Duli Yang Maha Mulia Ibrahim Sultan Yang Di Pertua bagi negeri-negeri dan jajahan Johor berkenaan dengan undangundang Tubuh Kerajaan pada fasal 49 dan 57 serta dengan persetujuan ahli-ahli Jawatan Keadilan dan agama telah bertitah berkenaan dan suka 
membenarkan supaya dipakai dan diperlakukan oleh sekalian pegawaipegawai, majistret-majistret dan hakim-hakim dalam kerajaan Johor "Majallat Ahkam al-Adliyyah" iaitu mana-mana dan atas perkara yang berkenaan dengan syarii hendaklah dipakai dan berpandukan "Majallat" yang tersebut dengan syarah-syarahnya. (J/UG X n.d.)

Keadaan ini menggambarkan bahawa mufti kerajaan Johor pada masa tersebut cuba untuk menerapkan elemen berteraskan Islam khususnya dari segi muamalat yang berkaitan dengan urusan ekonomi bagi kerajaan Johor. Perkenan daripada baginda sultan kemudiannya menjadikan perkara ini lebih kukuh untuk diikuti oleh pegawai-pegawai sama ada dalam jabatan-jabatan berkaitan kerajaan di samping individu yang mempunyai tugas di mahkamah-mahkamah. Antara perkara yang disentuh berkaitan muamalat dalam Majalah Ahkam al-Adliyyah adalah urusan jual beli, sewaan, konsep wakalah, dan pajakan. Dalam hal ini, terma-terma berkenaan adalah sangat rapat dengan urus tadbir ekonomi berasaskan Islam untuk kerajaan Johor. Tanpa satu panduan atau penjelasan terhadap perkara-perkara tersebut, urusan berkaitan dengannya pasti tidak dapat dilaksanakan mengikut kaedah serta prinsip dalam erti kata sebenar. Usaha tersebut begitu signifikan untuk mendepani pengaruh prinsip ekonomi konvensional pihak British. Konsep-konsep yang terkandung dalam Majalah Ahkam al-Adliyyah ini dimuatkan dalam sukatan pelajaran sekolah agama di Johor. Melalui usaha ini, penerapan prinsip-prinsip ekonomi berkaitan Islam kemudiannya dapat disampaikan kepada rakyat biasa terutamanya dalam kalangan murid di sekolah-sekolah dalam negeri Johor. Perlu ditegaskan di sini bahawa penyediaan Majalah Ahkam al-Adliyyah ini bukanlah kayu ukur terhadap kejayaan mutlak untuk menolak pengaruh British. Penyediaan majalah tersebut setidak-tidaknya dapat dilihat sebagai alternatif daripada pihak mufti untuk menghadapi pengaruh imperialisme dari segi ekonomi oleh pihak British.

Dalam hal ini, usaha mufti kerajaan Johor daripada tempoh pentadbiran Syed Salim al-Attas hingga Syed 'Abd. Qadir al-Attas telah menyaksikan bahawa wujudnya usaha untuk menghadapi pengaruh daripada imperialisme ekonomi oleh pihak British. Meskipun tindakan mufti-mufti tersebut tidak berupaya menghapuskan sama sekali kesan daripada imperialisme ekonomi berkenaan, tetapi sekurang-kurangnya para mufti terbabit telah cuba menghidupkan satu pentadbiran ekonomi berteraskan Islam. Melalui pengenalan kepada kedua-dua majalah tersebut, setidak-tidaknya golongan pentadbir kerajaan Johor dan rakyat ketika itu dapat memperoleh kefahaman serta garis panduan mengenai hal ehwal ekonomi berkaitan Islam. 


\section{Peranan Mufti dalam Aspek Sosial Kerajaan Johor (1885-1941)}

Pihak mufti turut memainkan peranan penting dalam pentadbiran kerajaan Johor melalui aspek sosial sewaktu imperialisme British. Penekanan khusus telah diberikan dalam dua aspek iaitu pendidikan rakyat Johor dan pengukuhan kefahaman tentang Islam dalam kalangan rakyat. Dalam perkara yang berkaitan pendidikan, isu ini amat penting dalam usaha untuk membangun dan membina peribadi masyarakat selaras dengan tuntutan Islam itu sendiri terhadap pentingnya ilmu pengetahuan. Dari segi falsafah pendidikan, perkara tersebut merupakan satu mekanisme yang membawa penekanan terhadap penanaman ilmu dan adab untuk menghasilkan manusia yang baik (Syed Muhammad Naquib 1995, 35). Dari segi pengukuhan kefahaman Islam dalam masyarakat pula, perkara berkenaan penting untuk memelihara akidah masyarakat yang sedang diasak oleh pengaruh agama Kristian yang dijelaskan sebelum ini. Sekiranya diteliti dengan lebih mendalam, tindakan daripada mufti-mufti kerajaan Johor ini dari segi pendidikan begitu penting kerana pentadbir British semakin giat membina institusi pendidikan berteraskan ajaran Kristian. Kawasan yang menjadi tumpuan pembinaan institusi pendidikan ini tertumpu di daerah Muar, Batu Pahat dan Johor Bahru (Rahimah 1997, 122). Bagi Muar dan Johor Bahru misalnya, kedua-dua kawasan terletak bersebelahan dengan NNS iaitu Melaka dan Singapura (Nabir 1990, 115; Baker 2005, 71). Justeru, pengaruh ajaran Kristian ini lebih mudah dan dekat untuk bergerak ke kedua-dua daerah tersebut dan hal ini terbukti dengan wujudnya sekolah mubaligh Kristian seperti Sekolah Convent di Johor Bahru dan Sekolah St. Andrew di Muar (Jabatan Pelajaran Johor n.d.). Dari segi impak kemasukan ajaran Kristian tersebut, perkara ini bukan sekadar memberi ancaman dari segi kepercayaan yang bersifat spiritual tetapi turut melibatkan soal syiar agama Islam kerana sekolah-sekolah yang dibina tersebut turut membawa binaan-binaan lain seperti tanda salib serta patung-patung yang sengaja diperlihatkan sebagai simbol kepercayaan ajaran Kristian.

Selain itu, impak imperialisme British terhadap keadaan sosial di Johor turut terlihat dengan semakin berleluasanya budaya hedonisme dalam kalangan masyarakat. Budaya hedonisme ini turut bercampur dengan budaya kuning yang jelas menjejaskan pemikiran serta kelakuan kebanyakan masyarakat di Johor sama ada di kawasan bandar mahupun di kawasan kampung (Izuan 2015, 180). Budaya tersebut tersebar dalam kalangan masyarakat melalui banyaknya pusat hiburan seperti panggung wayang di samping acara tari-menari yang memperlihatkan pergaulan bebas antara lelaki dengan perempuan. Kenyataan ini ada asasnya sehingga pentadbiran kerajaan Johor mengeluarkan arahan supaya program seumpama ini dihentikan kegiatannya. Buktinya, wujud perintah supaya panggung wayang ditutup untuk membendung masalah sosial yang hebat berlaku (J/MB 
n.d.). Pemuda-pemuda Melayu misalnya tidak berasa malu untuk menari bersama perempuan sebaliknya akan berasa malu jika tidak pandai menari (Idaman 1940). Bagi golongan pemudi pula, mereka cenderung untuk menggayakan fesyenfesyen dari Barat yang kononnya dilihat sebagai sebahagian daripada lambang kemodenan (Lembaga Malaya 1934).

Sebagai reaksi kepada keadaan sosial yang tidak menentu, barisan mufti negeri Johor dari penghujung kurun ke-19 hingga awal kurun ke-20 telah cuba untuk menggunakan saluran pendidikan sebagai alat untuk mengimbangi kesan imperialisme budaya oleh pihak British. Usaha memperkukuh sistem pendidikan berserta sukatan pelajarannya dilihat sebagai langkah terbaik bagi mengatasi masalah sosial ini. Pendekatan ini meskipun hanya boleh dilakukan dalam kalangan kanak-kanak atau remaja, tetapi setidak-tidaknya berupaya mencegah penularan imperialisme budaya sejak dari awal usia lagi. Secara asasnya, penekanan terhadap budaya ilmu melalui saluran pendidikan ini telah lama bermula di Alam Melayu sebaik sahaja Islam bertapak dan tersebar jauh sebelum berdirinya kerajaan Johor. Keadaan ini telah mengubah budaya masyarakat Melayu di samping pandangan alam (world view) dan perkara ini berterusan dari generasi ke generasi sebelum kedatangan kuasa-kuasa Barat lagi. Syed Muhammad Naquib al-Attas menegaskan perkara ini dalam karyanya, Islam dalam Sejarah dan Kebudayaan Melayu, dengan kenyataan berikut:

Jiwa masyarakat Melayu mulai mengalami penghidupan baru dengan mengalirnya unsur-unsur ini dalam nadinya, laksana raksa menjulang tinggi tersentuh sinaran surya baru! Timbulnya rasionalisme dan intelektualisme ini dapat kita bayangkan sebagai semangat nan hebat yang menggerakkan proses merevolusikan pandangan hidup masyarakat Melayu. (Syed Muhammad Naquib 1999, 19)

Rentetan daripada pembudayaan ilmu yang telah dibawa oleh Islam ke Alam Melayu, para mufti kerajaan Johor kemudiannya telah meneruskan kesinambungan ini untuk manfaat masyarakat. Dalam usaha untuk membangunkan nilai keinsanan berasaskan Islam, mufti kerajaan Johor khususnya Syed 'Abd Qadir telah melaksanakan tugas penting dengan menggubal sukatan pelajaran untuk bidang pendidikan di Johor. Penekanan awal mengenai pendidikan ini misalnya ditumpukan kepada golongan lelaki berbanding golongan perempuan. Hal ini dapat dilihat berdasarkan bilangan sekolah agama lelaki yang lebih banyak berbanding sekolah agama perempuan dan juga sukatan pelajaran yang disediakan. Buktinya, terdapat 47 buah sekolah agama lelaki yang menampung seramai 5,105 orang murid manakala hanya terdapat enam buah sekolah agama perempuan Johor dengan jumlah murid seramai 322 orang pada tahun 1933 (Rahimah 1997, 132; 
Nurul Wahidah 2012, 175). Hal ini menunjukkan bahawa pentadbiran kerajaan Johor tidak mengabaikan pendidikan untuk golongan perempuan meskipun jumlah sekolah yang dibina lebih sedikit berbanding sekolah bagi golongan lelaki. Hal ini timbul kerana sikap masyarakat Melayu pada waktu dahulu yang tidak menitikberatkan pendidikan untuk anak-anak perempuan, di samping kecenderungan masyarakat mengahwinkan anak perempuan mereka pada usia muda.

Dari segi tempoh masa persekolahan pula, tahap yang perlu dilalui oleh murid lelaki dan perempuan juga berbeza. Tempoh persekolahan murid perempuan akan berlangsung sehingga darjah empat manakala murid lelaki dikehendaki menyelesaikan persekolahannya sehingga darjah enam. ${ }^{14}$ Bagi sekolah agama perempuan, murid-murid diajar mengenal dan menyebut huruf jawi dan mereka kemudiannya akan diajar untuk mengeja ayat-ayat al-Quran yang terdapat dalam kitab mukaddam daripada Surah al-Fatihah sehingga Surah al-Ikhlas seterusnya membaca surah-surah lain dalam mukaddam hingga Surah adh-Dhuha semasa darjah satu. Usaha untuk mendidik murid perempuan seawal usia ini dengan kaedah membaca al-Quran adalah penting supaya mereka dapat membaca surahsurah berkenaan sewaktu solat. Lanjutan daripada itu, murid-murid berkenaan akan diajar menunaikan solat dengan berpandukan kitab Pertolongan Kanakkanak dan Pandai Melakukan Fiil Solat (J/UG 7 8/33 n.d.). Pada peringkat awal persekolahan, pendidikan lebih tertumpu kepada konsep 4M iaitu mengenal huruf, menyebut, mengeja dan membaca. Hal ini penting kerana keupayaan seseorang murid untuk menguasai keempat-empat tahap ini akan memudahkan mereka untuk ke peringkat pelajaran seterusnya di samping mudah memahami ilmu pengetahuan yang disampaikan oleh guru terlibat.

Selain itu, murid-murid tersebut dikehendaki membaca Surah al-Baqarah ketika mereka berada di darjah dua di samping tugasan untuk menghafal surah-surah lazim iaitu Surah al-Kauthar hingga Surah adh-Dhuha. ${ }^{14}$ Pada peringkat ini juga, mereka mula diperkenalkan dengan ilmu Tauhid melalui kitab-kitab yang dibekalkan oleh pejabat agama. Ketiga-tiga komponen ilmu agama ini adalah penting untuk membentuk peribadi Muslim dalam kalangan murid dengan pengukuhan terhadap ilmu tauhid yang diterjemahkan melalui ibadah solat dan dilengkapkan dengan pengetahuan terhadap al-Quran seawal usia kanak-kanak lagi. Perlu ditegaskan di sini bahawa peruntukan sukatan pelajaran tersebut telah disusun oleh barisan mufti Johor selepas mengambil kira keperluan untuk rakyat Johor terhadap pengetahuan berasaskan Islam. Dato' Abdullah Musa misalnya telah berutus surat dengan Tok Kenali dari Kelantan bagi bertanyakan beberapa persoalan sama ada dari segi ilmu Tauhid, ibadah mahupun muamalah untuk dijadikan sebagai pengisian 
kepada penerapan pengetahuan berasaskan Islam bagi rakyat Johor (J/UG 1 1939). Hal ini penting untuk membuktikan bahawa pengisian ilmu agama di Johor pada masa tersebut bukanlah sesuatu yang beku dari segi orientasi pengajarannya.

Seterusnya, sewaktu berada di darjah tiga, murid dikehendaki membaca al-Quran daripada Surah Ali 'Imran sehingga Surah Maryam serta diajar ilmu tajwid bagi memperbetulkan bacaan mereka. Peringkat ini merupakan titik penting untuk murid-murid tersebut mengenal dan menguasai secara teknikal dalam bacaan al-Quran dengan perkara-perkara yang berkaitan soal makhraj, sifat huruf dan tanda baca yang lebih spesifik. Pada masa yang sama, mereka akan menyambung mata pelajaran Tauhid yang dipelajari semasa darjah dua dan diubah pula dengan tiga mata pelajaran baharu iaitu Ibadat, Adab Perempuan yang Pertama serta Permulaan yang Kedua. Jika diteliti, langkah mengajar mata pelajaran Adab Perempuan yang Pertama pada darjah tiga merupakan usaha mufti Johor untuk menerapkan nilai-nilai murni dalam kalangan kanak-kanak perempuan agar tidak terpengaruh dengan budaya Barat sewaktu dewasa kelak. Melalui pengisian ilmu berkaitan adab, perkara ini sekali gus menjadi pelengkap kepada usaha untuk membentuk murid yang bukan sahaja cemerlang dari segi akademik tetapi turut membangunkan sahsiah murid itu sendiri.

Setelah memasuki darjah empat, murid-murid perempuan dikehendaki membaca al-Quran daripada Surah Tahaa sehingga khatam. Ilmu tajwid mereka turut dipertingkatkan melalui pembelajaran berdasarkan kitab Ithaf Al-Mar'rid. Selain itu, murid-murid juga akan terus mendalami subjek Tauhid di samping mata pelajaran lain seperti Ibadat yang diajar berdasarkan kitab yang dibekalkan oleh pejabat agama serta Permulaan yang Ketiga dan Adab Perempuan yang Kedua. Berdasarkan sukatan pelajaran yang diajarkan kepada murid perempuan, dapat dirumuskan bahawa pada peringkat awal, objektif utama pelajaran sekolah agama adalah untuk membudayakan para pelajar dengan ajaran agama Islam dengan memfokus kepada amalan membaca dan menghafal ayat-ayat al-Quran. Sekitar tahun 1909 misalnya, Syed 'Abd Qadir merupakan watak penting yang berusaha menyediakan ruang pendidikan kepada kanak-kanak perempuan dan perkara tersebut mirip dengan tuntutan Kaum Muda yang ketika itu giat menyuarakan keperluan pendidikan khususnya melalui majalah Al-Imam. Malahan, Al-Imam bukan sahaja mendesak supaya golongan perempuan mendapat pendidikan tetapi golongan tersebut turut dituntut agar diberikan hak perwarisan harta (Watson dan Andaya 2001, 208; Siti Zahrah 2018, 7). Hal ini membuktikan bahawa idea daripada mufti kerajaan Johor bagi membela hak golongan perempuan tidak terpisah dengan idea reformasi Kaum Muda yang semakin meluas pada tempoh itu. 
Bagi murid lelaki yang berada di darjah empat pula, sukatan pelajaran untuk mereka adalah berbeza dengan murid perempuan. Hal ini kerana murid-murid lelaki akan dilengkapi dengan ilmu yang akan membantu mereka menjadi seorang suami dan ketua keluarga. Sukatan pelajaran untuk mereka kemudiannya diisi dengan penghafalan wirid-wirid lazim solat berserta doanya di samping doa-doa untuk majlis tahlil. ${ }^{15}$ Hal ini selaras dengan peranan dan tanggungjawab yang perlu digalas oleh murid-murid lelaki sewaktu dewasa kelak iaitu sebagai imam dalam sesebuah keluarga. Pada masa yang sama, murid-murid lelaki pada darjah empat turut akan diajar Permulaan yang Ketiga dari kitab pejabat agama serta kitab adab Al-Fassi Al-Jazza 'i.

Sebagai tambahan, murid lelaki ini akan diajar dengan ilmu muamalat sewaktu di darjah lima untuk membolehkan mereka dididik dengan pengetahuan yang akan digunakan oleh mereka sewaktu bercampur dengan masyarakat. Keadaan ini memperlihatkan usaha pihak mufti Johor untuk menerapkan prinsip dan panduan mengenai muamalat berasaskan Islam di peringkat sekolah lagi. Di samping itu, murid lelaki juga akan diajar mata pelajaran munakahat agar mampu mengemudi sebuah keluarga kelak dengan nilai keislaman. Pada masa yang sama, murid juga akan diajar Pelajaran Permulaan yang Keempat dan Tauhid berdasarkan kitab Al-sa'ngaddah la Bid'iah yang menekankan soal ilmu tauhid yang lebih luas selaras dengan prinsip Ahli Sunnah Wal Jamaah yang menjadi ikutan dalam kalangan masyarakat Johor. Seterusnya, pada peringkat akhir iaitu darjah enam, murid-murid akan diajar kitab Matla'il Badrin, kitab adab Al-Fassi Al-Jazza'i, kitab Hidayatul Sallakin Tasawuf, kitab Ahkam Syariah serta sebagai tambahan, murid akan diperkenalkan dengan mata pelajaran Faraid iaitu berkenaan pembahagian harta pusaka (J/UG 1 1939; Abdul Latif dan Jainal 2008, 80; Nurul Wahidah 2012, 233).

Selanjutnya, sewaktu Syed "Alwi Tahir al-Haddad menjawat jawatan mufti, sukatan pelajaran di Sekolah Agama telah dirombak oleh Pejabat Pelajaran Johor pada tahun 1936 atas tujuan penambahbaikan. Murid-murid darjah satu akan diajar mata pelajaran Tauhid, Ibadat dan mengeja mukaddam. Setelah memasuki darjah dua, mereka akan mempelajari ilmu Tauhid, Ibadat, Tawarikh dan al-Quran. Seterusnya, bagi murid dalam darjah tiga mereka akan mempelajari subjek seperti Tauhid, Ibadat, Tajwid al-Quran, Adab Perangai, Tawarikh dan al-Quran. Bagi murid darjah empat hingga enam pula, mereka akan diajar mata pelajaran seperti Tauhid, Muamalat, Munakahat, Adab Perangai, Tasawuf, Tajwid al-Quran, Jenayat dan al-Quran (Izuan 2015, 152). Untuk murid-murid Darjah Khas, mereka akan diajar mata pelajaran yang diajarkan kepada murid darjah empat hingga enam secara lebih terperinci dan mendalam. Di samping itu, murid 
Darjah Khas juga akan dibekalkan pendidikan bahasa Arab dan bahasa Melayu melalui mata pelajaran Pedoman Mengajar Permulaan Bahasa Arab dan Bahasa Melayu. Kesungguhan mufti kerajaan Johor khususnya di bawah kepimpinan Syed 'Alwi Tahir al-Haddad dan para mufti sebelumnya dalam menggubal sukatan pelajaran sekolah agama Johor menjadi bukti bahawa wujudnya usaha untuk memelihara masyarakat Johor daripada terpengaruh dengan imperialisme budaya yang dijelaskan sebelum ini. Persoalannya di sini, apakah usaha daripada pihak mufti ini turut disokong oleh pentadbiran kerajaan Johor? Bagaimanakah golongan pentadbir kerajaan Johor memastikan bahawa ibu bapa menghantar anak-anak mereka supaya mengikuti program pendidikan yang telah digubal? Bertitik tolak daripada persoalan ini, pentadbiran kerajaan Johor yang turut melibatkan mufti sebagai ahli Jemaah Negeri telah melaksanakan undang-undang yang mewajibkan ibu bapa menghantar anak-anak mereka ke sekolah. Pada tahun 1902, satu peraturan pelajaran yang baharu telah dibuat yang menyatakan bahawa ibu bapa bertanggungjawab menghantar anak lelaki mereka ke sekolah dan jika tidak, mereka akan didenda $\$ 25$ atau tiga bulan penjara. Bagi menjalankan undang-undang ini, seorang mata-mata sekolah dilantik di bawah pengawasan guru-guru besar sekolah. Undang-undang ini nampaknya telah berjaya mengatasi masalah sikap penduduk setempat yang tidak berminat terhadap pelajaran. Berdasarkan laporan-laporan yang sedia ada, bilangan sekolah vernakular Melayu telah berlipat ganda. Misalnya, bilangan sekolah vernakular Melayu pada tahun 1911 telah bertambah menjadi 18 buah semuanya. Peratus kedatangan muridmurid juga telah bertambah dan bilangan orang Melayu yang boleh membaca dan menulis juga sangat menggalakkan (General Adviser 72/1912 1912).

\section{Kesimpulan}

Kesimpulannya, kajian ini telah membuktikan bahawa kedudukan mufti dalam pentadbiran kerajaan Johor adalah penting semasa era imperialisme British. Kepentingan tersebut terbukti melalui usaha-usaha yang dibuat oleh mufti yang terlibat khususnya dalam pentadbiran ekonomi dan sosial bagi kerajaan Johor. Hal ini terlihat daripada aspek-aspek seperti pentadbiran baitulmal, pengenalan Majalah Ahkam al-Adliyyah dan Majalah Ahkam Johor sebagai panduan pentadbiran kerajaan Johor di samping idea para mufti dalam institusi pendidikan.

Melalui dokumen-dokumen daripada arkib, kedudukan mufti dalam kerajaan Johor ternyata tidak tertumpu hanya kepada urusan hal ehwal agama, sebaliknya turut mencakupi aspek pentadbiran kerajaan Johor itu sendiri. Setiap mufti yang berkhidmat dari tahun 1885 sehingga 1941 telah memastikan impak daripada imperialisme British dapat diminimumkan khususnya dalam konteks ekonomi. Pentadbiran baitulmal dan pengenalan Majalah Ahkam al-Adliyyah dan Majalah 
Ahkam Johor jelas menunjukkan usaha mufti kerajaan Johor untuk mewujudkan suasana pentadbiran yang berteraskan Islam. Hal ini sedikit sebanyak menjadi pelengkap kepada pentadbiran kerajaan Johor yang cuba mendepani imperialisme ekonomi British yang bercorak kebaratan.

Dari segi sosial, kedudukan mufti jelas berfungsi ketika penggubalan sukatan pelajaran bagi sekolah-sekolah di Johor yang menjadi fokus dalam perbincangan. Tindakan ini penting bagi memastikan murid-murid pada masa itu mendapat keperluan dari segi kandungan pendidikan berasaskan Islam sama ada dari segi tauhid, fikah mahupun akhlak. Usaha para mufti kerajaan Johor pada tempoh ini perlu dilihat sebagai suatu yang positif bagi menghalang imperialisme budaya British yang mengandungi unsur hedonisme dan pengkristianan. Jelaslah bahawa barisan mufti kerajaan Johor dari tahun 1885 hingga 1941 telah memainkan peranan penting dalam memastikan aspek ekonomi dan sosial kerajaan Johor tidak tergugat oleh peluasan imperialisme British ketika itu yang cuba menyelinap dari segenap penjuru.

\section{Rujukan}

Abdul Jalil Borham. 2002. Majalah Ahkam Johor: Latar belakang, pelaksanaan dan komentar. Johor, Malaysia: Penerbit Universiti Teknologi Malaysia.

Abdul Latif Juffri@al-Jufri. 2012. 40 tokoh ulama Johor. Johor, Malaysia: Badan Kebajikan Pejabat Kadi Daerah Muar.

Abdul Latif Juffri@al-Jufri and Jainal Sakban al-Jauhari. 2008. Sejarah perkembangan Jabatan Agama Islam Johor. Johor, Malaysia: MAIJ URUS.

Abdul Rahman Tang Abdullah. 2007. Interpreting Abu Bakar, the ruler of Johor (18621895): The reconstruction of selected issues. PhD diss., University of London.

Abu Bakar A. Hamid and Md Ismail Zamzam. 2003. Tokoh ternama Johor. Johor, Malaysia: Yayasan Warisan Johor.

Ahmad Fathy al-Fatani. 2009. Ulama besar dari Patani. Kelantan, Malaysia: Majlis Agama Islam Kelantan.

Ahmad Fawzi Basri. 1997. Undang-Undang Tubuh Kerajaan Johor 1312 (1895): Kepentingannya dari segi persuratan dan sejarah. Johor, Malaysia: Yayasan Warisan Johor.

1988. Johor 1855-1917: Pentadbiran dan perkembangannya. Selangor, Malaysia: Penerbit Fajar Bakti Sdn. Bhd.

Baker, J. 2005. The eagle in the Lion City: America, Americans and Singapore. Singapore: Landmark Books Pte Ltd.

CO 273/406. 1914. Fail Pejabat Colonial. M.H. Whitley memo. 19 February. Pulau Pinang, Malaysia: Perpustakaan Hamzah Sendut, Universiti Sains Malaysia.

CO 273/416. 1877. Further memorandum regarding to the history of Sultan Ali's family and of his affairs. 4 August. Johor, Malaysia: Arkib Negara Malaysia Cawangan Johor. 
Cowan, C.D. 1961. Nineteenth century Malaya: The origins of British political control. London: Oxford University Press.

Eeman Mohamed Abbas. 2002. Sultan 'Abd Al-Hamid II dan kejatuhan Khilafah Islamiyyah: Peranan gerakan nasionalis dan golongan minoriti. Kuala Lumpur: Pustaka Salam Sdn. Bhd.

Emerson, R. 1964. Malaysia: A study in direct and indirect rule. Kuala Lumpur: University of Malaya Press.

Gallagher, J. and Robinson, R. 1981. Africa and the victorians: The official mind of imperialism. London: Macmillan Education.

General Adviser 72/1912. 1912. School attendance enactment. Johor, Malaysia: Arkib Negara Malaysia Cawangan Johor.

Hobson, J.A. 1902. Imperialism: A study. Madison, MI: The University of Michigan Press.

Ichiro, S. 2011. Pentadbiran kewangan kolonial Johor. Kuala Lumpur: Penerbit Universiti Malaya.

Idaman. 1940. Apa akal?, 1 July. Johor, Malaysia: Arkib Negara Malaysia Cawangan Johor.

Ismail Che Daud. 1992. Tokoh-tokoh ulama Semenanjung Melayu. Kelantan, Malaysia: Majlis Agama Islam Kelantan.

Jabatan Pelajaran Johor. n.d. Sejarah sekolah-sekolah Johor. Johor, Malaysia: Jabatan Pelajaran Johor.

J/DUN 7. 1934. Buku senarai Ahli Majlis Mesyuarat Kerajaan Negeri Johor 1934 dan 1936. Johor, Malaysia: Arkib Negara Malaysia Cawangan Johor.

J/MB. n.d. Pejabat Menteri Besar Johor. Johor, Malaysia: Arkib Negara Malaysia Cawangan Johor.

J/PP 11 4. 1910. Perundangan Tanah Johor 1910. Johor, Malaysia: Arkib Negara Malaysia Cawangan Johor.

J/PU 1. 1936. Undang-undang tanah yang mencadangkan kerana orang-orang Melayu bilangan 1 tahun 1936. Johor, Malaysia: Arkib Negara Malaysia Cawangan Johor.

J/PU 3. 1895. Undang-Undang Tubuh Kerajaan Johor 1895. Johor, Malaysia: Arkib Negara Malaysia Cawangan Johor.

J/SUK 11. 1896a. Kongkek dan Kongsoh: Candu, salinan surat-surat Datuk Menteri (SSDM). 3 September. Johor, Malaysia: Arkib Negara Malaysia Cawangan Johor.

1896b. Pajak judi orang Islam, salinan surat-surat Datuk Menteri (SSDM). 3 August. Johor, Malaysia: Arkib Negara Malaysia Cawangan Johor.

J/UG 1. 1939. Penyata sekolah agama Johor dan daerahnya bagi tahun 1939. Johor, Malaysia: Arkib Negara Malaysia Cawangan Johor.

J/UG 7 8/33. n.d. Sukatan pelajaran sekolah agama Johor. Johor, Malaysia: Arkib Negara Malaysia Cawangan Johor.

J/UG X. n.d. Majalah Ahkam Johor. Johor, Malaysia: Arkib Negara Malaysia Cawangan Johor.

Khoo, K.K. 1972. The western Malay states, 1850-1873: The effects of commercial development on Malay politics. New York: Oxford University Press.

Lafeber, W. 1967. The new empire: An interpretation of American expansion 1860-1898. London: Cornell University Press. 
Lembaga Malaya. 1934. Pakaian perempuan Melayu, 31 December. Johor, Malaysia: Arkib Negara Malaysia Cawangan Johor.

Lenin, V.I. 1939. Imperialism, the highest stage of capitalism: A popular outline. New York: International Publishers.

Muhammad Izuan Abdul Rahman. 2015. Peranan pemerintah dan golongan intelektual dalam memperjuangkan identiti dan kedaulatan Johor, 1862-1957. MA diss., Universiti Sains Malaysia.

Nabir Haji Abdullah. 1990. Imperialisme budaya: Peranan mubaligh Kristian di Tanah Melayu dan Singapura sebelum merdeka. In Kolonialisme di Malaysia dan negaranegara lain, eds. Cheah B.K. and Abu Talib Ahmad, 110-158. Selangor, Malaysia: Penerbit Fajar Bakti Sdn. Bhd.

Nadarajah, N. 2000. Johore and the origins of British control, 1895-1914. Kuala Lumpur: Arena Buku.

Nurul Wahidah Fauzi. 2012. Ulama Arab Hadhrami dalam pentadbiran dan pendidikan Islam di Johor: Analisis terhadap sumbangan Syed 'Abd Qadir bin Muhsin al-Attas dan Syed 'Alwi b. Tahir al-Haddad. PhD diss., Universiti Malaya.

Parkinson, C.N. 1960. British intervention in Malaya. Singapore: University of Malaya Press.

Perjanjian Pesahabatan 1885. Johor, Malaysia: Arkib Negara Malaysia Cawangan Johor.

Rahimah Abdul Aziz. 1997. Pembaratan pemerintahan Johor (1800-1945): Suatu analisis sosiologi sejarah. Kuala Lumpur: Dewan dan Bahasa Pustaka.

S.7. 1857. Salinan surat nasehat wasiat Almarhom Ungku Temenggong Ibrahim Sri Maharaja Johor kepada paduka anakandanya Encik Wan Abu Bakar, 24 Zulhijah 1273. Johor, Malaysia: Arkib Negara Malaysia Cawangan Johor.

n.d. Salinan wasiat Almarhum Sultan Abu Bakar. Johor, Malaysia: Arkib Negara Malaysia Cawangan Johor.

Sadka, E. 1968. The protected Malay states, 1874-1895. Kuala Lumpur: University of Malaya Press.

Sinclair, K. 1967. Hobson and Lenin in Johore: Colonial Office policy towards British concessionaires and investors, 1818-1907. Modern Asian Studies 1(4): 335-352. https://doi.org/10.1017/S0026749X0000264X

Siti Zahrah Mahfood. 2018. Kedudukan politik dan sosioekonomi masyarakat Melayu dalam akhbar dan majalah terbitan negeri Johor sebelum Perang Dunia Kedua. PhD diss., Universiti Sains Malaysia.

Syed Muhammad Naquib al-Attas. 1999. Islam dalam sejarah dan kebudayaan Melayu. Kuala Lumpur: Penerbit Universiti Kebangsaan Malaysia.

1995. Prolegomena to the metaphysics of Islam: An exposition of the fundamental elements of the worldview of Islam. Selangor, Malaysia: International Institute of Islamic Thought and Civilization.

Syed Nurul Akla Syed Abdullah and Adi Setia Mohd Dom, trans. 2003. Pengembaraan Ibn Battutah: Pengembara agung, karya terulung, menyingkap wajah dunia. Kuala Lumpur: Institut Kefahaman Islam Malaysia (IKIM).

Thompson, A. 2005. The empire strikes back?: The impact of imperialism on Britain from the mid-nineteenth century. London: Pearson, Longman. 
Turnbull, C.M. 1972. The Straits Settlement 1826-67: Indian presidency to crown colony. Singapore: Oxford University Press.

Watson, B. and Andaya, L. 2001. A history of Malaysia. Basingstoke, UK: Palgrave.

Wong, G.L. 1990. Campur tangan Inggeris dan kepentingan ekonomi: Kes Pahang Corporation Limited, 1880-88. In Kolonialisme di Malaysia dan negara-negara lain, eds. Cheah B.K. and Abu Talib Ahmad, 110-158. Selangor, Malaysia: Penerbit Fajar Bakti Sdn. Bhd.

Yegar, M. 1979. Islam and Islamic institutions in British Malaya. Jerusalem: The Magnes Press, The Hebrew University. 